\title{
The feasibility of a fixed exchange rate regime for new EU-members: evidence from real exchange rates
}

Citation for published version (APA):

Candelon, B., Kool, C. J. M., Raabe, K., \& van Veen, A. P. (2005). The feasibility of a fixed exchange rate regime for new EU-members: evidence from real exchange rates. METEOR, Maastricht University School of Business and Economics. METEOR Research Memorandum No. 011 https://doi.org/10.26481/umamet.2005011

Document status and date:

Published: 01/01/2005

DOI:

10.26481/umamet.2005011

Document Version:

Publisher's PDF, also known as Version of record

\section{Please check the document version of this publication:}

- A submitted manuscript is the version of the article upon submission and before peer-review. There can be important differences between the submitted version and the official published version of record.

People interested in the research are advised to contact the author for the final version of the publication, or visit the DOI to the publisher's website.

- The final author version and the galley proof are versions of the publication after peer review.

- The final published version features the final layout of the paper including the volume, issue and page numbers.

Link to publication

\footnotetext{
General rights rights.

- You may freely distribute the URL identifying the publication in the public portal. please follow below link for the End User Agreement:

www.umlib.nl/taverne-license

Take down policy

If you believe that this document breaches copyright please contact us at:

repository@maastrichtuniversity.nl

providing details and we will investigate your claim.
}

Copyright and moral rights for the publications made accessible in the public portal are retained by the authors and/or other copyright owners and it is a condition of accessing publications that users recognise and abide by the legal requirements associated with these

- Users may download and print one copy of any publication from the public portal for the purpose of private study or research.

- You may not further distribute the material or use it for any profit-making activity or commercial gain

If the publication is distributed under the terms of Article $25 \mathrm{fa}$ of the Dutch Copyright Act, indicated by the "Taverne" license above, 


\title{
THE FEASIBILITY OF A FIXED EXCHANGE RATE REGIME FOR NEW EU-MEMBERS: EVIDENCE FROM REAL EXCHANGE RATES
}

\author{
Bertrand Candelon $^{a}$, Clemens Kool ${ }^{b}$, Katharina Raabe ${ }^{a}$ and Tom van Veen ${ }^{a}$
}

\author{
FIRST DRAFT, NOT TO BE QUOTED \\ MARCH 2005
}

\begin{abstract}
In this paper, we estimate fundamental bilateral real exchange rates for a group of eight accession countries using a panel-cointegration approach for the period 1993-2003. We document a significant positive link between productivity levels and the corresponding real exchange rate levels. Future rises in productivity cannot be excluded on the basis of either our own analysis or the literature as a whole. Consequently, inflation pressure and real exchange rate appreciation in the accession countries probably remain a fact of life in the near future. The extent to which this is a problem for a fixed nominal exchange rate regime is hard to determine. Price dynamics in the accession countries are still quite flexible to accommodate substantial real exchange rate movements even when the nominal exchange rate is rather fixed; moreover, that price adjustment is mostly an internal process for the accession countries. Overall we conclude that a fixed exchange rate regime for each of the accession countries would be feasible in itself, despite possible future real exchange rate appreciations due to either the Balassa-Samuelson effect or demand shifts. We find current misalignments to be small, robust and generally in line with the literature. This implies current exchange rate levels provide a reasonable indication of the level at which a parity exchange rate could be set.
\end{abstract}

Keywords: real exchange rate, misalignments, Balassa-Samuelson, panel cointegration JEL Classification: F31, F4, C23

a'University of Maastricht, Department of Economics, Maastricht, The Netherlands

${ }^{\mathrm{b}}$ Utrecht School of Economics, University of Utrecht, The Netherlands

\section{Acknowledgements}

A previous version of this work has constituted a report for the Ministry of Finance of the Netherlands. We are grateful for its financial support as well as for comments. We also thank Nikki Frank and Jeroen van den Berg for excellent assistance in the research. All errors and omissions remain ours. 


\section{Introduction}

As of May 1, 2004, ten countries have joined the European Union: Cyprus, the Czech Republic, Estonia, Hungary, Latvia, Lithuania, Malta, Poland, Slovenia, and Slovakia. Previously, most of these countries had centrally planned economies. Over the past decade, they have gone through a severe transition process towards a market economy. In terms of nominal exchange rate regimes and actual exchange rate developments, large differences can be noted across these countries over the past ten years. Some started with a relatively fixed exchange rate regime and switched to (managed) floating at some point, others worked the other way around with a relatively floating regime in the early nineties and a move to more fixed regimes in the second half of that decade. All of them still have their own currency and monetary autonomy. However, they share the same long-run perspective of participating in the Economic and Monetary Union and adopting the euro as the common currency.

A major issue in this respect is the choice of transition strategy for each of these countries. Estonia, Lithuania and Slovenia already entered ERM-II in June 2004. Other countries will presumably follow in due time. Clearly, the choice of an appropriate parity nominal exchange rate and the choice of the magnitude of the fluctuation margin will depend on the underlying fundamental determinants of the bilateral real exchange rates relative to the euro and on their predicted variability. For these countries the development of the real exchange rate is most important because trend-like real appreciations caused by for example the Balassa-Samuelson effect may be hard to reconcile with a fixed exchange rate regime. More generally, knowledge of real exchange rate determinants may be of help in assessing the readiness of each country to move to the EMU.

In this paper, we analyze the fundamentals behind the real exchange rate for eight of the ten accession countries for the period from 1993 to $2003^{1}$. In particular we are interested in the long-run components of the real exchange so as to calculate misalignments. Although many studies exist for particular countries, e.g. the Czech Republic, Hungary, and Poland, only few are available for the whole group of accession countries. In addition, the econometric methodology varies across existing work, being determined by the availability of either time-series or panel data. Here, we extend the

\footnotetext{
${ }^{1}$ Due to a lack of data, Malta and Cyprus had to be excluded from the analysis.
} 
existing literature through a uniform panel cointegration analysis for eight accession countries together. We focus on the external and on the internal real exchange rate and conclude that both have caused the real exchange rate to appreciate, albeit to a different extent in the various countries. The remainder of the paper is structured as follows. In Section 2, we develop the concept of the real exchange rate and present the theoretical model as well as its empirical specification. We present and motivate the data and the choice of the panel cointegration technique in Section 3. The corresponding empirical results are discussed in Section 4. Section 5 concludes.

\section{The real exchange rate: theoretical concepts and empirical application}

We define the nominal exchange rate $\left(E_{i}\right)$ for each accession country $i$ as the price of one unit of the accession country's currency in terms of the euro $(€)$. The corresponding real exchange rate $\left(Q_{i}\right)$ is the relative price of a standard basket of goods in the accession country compared to the price of the same basket in the Euro area. We denote the Euro area price level by $P^{*}$ and accession country's $i$ price level by $P_{i}$. Then, the real exchange rate is defined as

$$
Q_{i}=\left(E_{i} P_{i} / P^{*}\right)
$$

The real exchange as defined in equation (1) reflects the competitive position of a country. According to the strict version of purchasing power parity (PPP) hypothesis, $Q_{i}$ will equal unity. Less narrow versions allow $Q_{i}$ to be equal to some arbitrary constant. Under the assumptions that all goods are tradable (and homogeneous across countries) and in the absence of trade barriers, competition will ensure that PPP holds, if not in the short run then at least in the longer run. Temporary deviations from PPP will be eliminated over time.

In practice, both tradable and non-tradable goods exist. To accommodate this phenomenon, we assume that a country's price index $P$ is a geometrically weighted average of the price indexes of 
tradable and non-tradable goods. The weights are given by the share of the tradable goods $(\alpha)$ and non-tradable goods (1- $\alpha)$ in the total added value of a country. Equation (1) then can be rewritten as:

$$
Q_{i}=E_{i \cdot}\left(P_{i}{ }^{T} / P^{T^{*}}\right) \cdot\left(P_{i}{ }^{N} / P_{i}{ }^{T}\right)^{(1-\alpha)} \cdot\left(P^{T^{*}} / P^{N^{*}}\right)^{(1-\alpha)}
$$

From equation (2) one immediately infers that the real exchange rate is a combination of three factors: i) the real exchange rate for tradable goods $E\left(P^{T} / P^{T *}\right)$, ii) the price ratio of non-tradable goods and tradable goods in the respective accession country $\left(P^{N} / P^{T}\right)$, and iii) the price ratio of non-tradable goods and tradable goods in the euro area country $\left(P^{N^{*}} / P^{T *}\right)$. We refer to the first variable as the external real exchange rate $Q_{l}$, while the other two terms are denoted the accession country's and the euro area's internal real exchange rate $Q_{2}$ and $Q_{2}{ }^{*}$, respectively. Equation (2) then can be reformulated as:

$$
Q_{i}=Q_{1 i \cdot}\left[Q_{2 i} / Q_{2}^{*}\right]^{(1-\alpha)}
$$

For a thorough analysis of the overall real exchange rate $Q_{i}$, determinants of both the internal and external real exchange rates need to be considered. If all tradable goods are traded on perfectly competitive markets, arbitrage equilibrates the external real exchange rate to 1 . However, a number of factors may prevent the external exchange rate from being unity continuously or even to move towards it in the long run. For the internal real exchange rate, no unique equilibrium value can be defined a priori.

To model the determinants of both the internal and external real exchange rate more precisely, we take an approach similar to Égert and Larèche-Révil (2003). They assume that the real exchange rate plays a role in generating both external and internal equilibrium in the economy. In their view, the external real exchange rate $\left(Q_{l}\right)$ takes care of external equilibrium, which is defined as a sustainable current account position. The internal real exchange rate $\left(Q_{2}\right)$ serves to equilibrate supply and demand for domestic non-tradables. The resulting (reduced-form) model looks as follows: 


$$
\begin{aligned}
& Q_{1 t}=d_{0}+d_{1} C A_{t}+d_{2} \text { DEBT }_{t}+d_{3} \text { OPEN }_{t}+u_{2 t}, \\
& Q_{2 t}=c_{0}+c_{1} \text { PROD }_{t}+c_{2} \text { DEMAND }_{t}+u_{1 t},
\end{aligned}
$$

where $C A$ stands for current account, $D E B T$ for foreign debt and $O P E N$ for openness; PROD stands for productivity, $D E M A N D$ is a demand variable.

To motivate equation (4), we note first that a country's current account position is central to the concept of external equilibrium. A (structural) current account deficit reflects an excess demand for foreign tradable goods. To equilibrate the current account, a real depreciation then is required, implying coefficient $d_{1}$ is expected to be positive. Note, however, that we may find a negative coefficient due to reverse causality. An appreciated real exchange rate may in the medium run yield a current account deficit. Second, a large external debt position implies interest and principal payment commitments abroad that need to be financed by net exports. The higher the stock of net foreign liabilities, the higher the structural trade surplus should be and the more depreciated the country's domestic currency value in real terms. Consequently, we hypothesize $d_{2}$ to be negative. Finally, starting from a situation in which the domestic economy is constrained in its trade relations, an increase in openness often represents a cut in tariff and non-tariff protection. In the literature, it is generally assumed that this will lead to a higher domestic demand for foreign tradable goods and a rise in their relative price. Consequently, a domestic real depreciation would result, suggesting a negative sign for coefficient $d_{3}$. Again, however, the coefficient's sign is ambiguous. An increase in openness can also work the other way as it opens the way for higher foreign demand for domestic products and correspondingly higher exports. In the case of the accession countries, closer integration with the EU not only raises their imports but their exports as well. ${ }^{2}$

\footnotetext{
${ }^{2}$ In some models, a Terms of Trade variable explicitly enters the external equilibrium equation. Égert and Larèche-Révil (2003), for instance, relate the CA to the terms of trade and in a second step relate the overall real exchange rate to the current account. In our view, this is inappropriate as the terms of trade - measured as the relative price of domestic exports and domestic imports - are closely related to the external exchange rate. Including the Terms of Trade as an explanatory variable for the real exchange rate then overstates the actual predictability of the real exchange rate.
} 
In equation (5), two variables have an impact on the internal real exchange rate. ${ }^{3}$ First, the use of the productivity variable is derived from the Balassa-Samuelson theory. According to this theory, less developed countries will typically experience a structural appreciation of the internal real exchange rate when they catch up with more developed countries. In the catching-up process, productivity in the domestic tradable goods sector will increase relative to that in the non-tradable goods sector. Under the assumptions that wage setting in the tradable goods sector leads wage setting in the non-tradable goods sector and that wages in the tradable and non-tradable sector will equalize due to domestic labour mobility, prices of domestic non-tradable goods increase relative to domestic prices of tradable goods. In other words, an appreciation of the internal real exchange rate occurs. Underlying this appreciation is a growing productivity differential between tradables and nontradables. The variable PROD in equation (5) represents this effect. We hypothesize a negative coefficient $c_{1 \cdot}{ }^{4}$

Additionally, equation (5) contains the variable DEMAND. In the literature, it has been argued that in the catching-up process an increase in demand for non-tradables relative to tradables will occur, causing an appreciation of the internal real exchange rate as well. Here, the argument is that the composition of the standard consumption bundle will shift in the direction of non-tradable goods (and services) with an increase in income and wealth. If so, coefficient $c_{2}$ will be negative. In practice, the catching up process of developing countries may simultaneously be an opening up process with the rest of the world, resulting in a (temporary) increase in demand for tradable relative to non-tradables and, thus, to an opposite effect. Again, the coefficient is ambiguous.

\footnotetext{
${ }^{3}$ Relatively few empirical studies assess the relevance of monetary variables like interest rates and money supply as real exchange rate determinants (Smidkova et al. (2002), Lommatzsch and Tober (2002), Crespo Cuaresma et al. (2003), Randveer and Rell (2002)). The limited interest in these variables is attributable to two aspects. Firstly, in the long run the money supply only determines the price level. Secondly, the real interest rate only clears the goods market in a large, but not in a small domestic economy. In the present framework, it would only be sensible to include the real interest rate if we were to discuss short-term deviations from the long run equilibrium. Given these properties, the present study excludes monetary variables and only focuses on the role of productivity and demand variables as determinants of the real exchange rate and on the clearance of the goods market via the real exchange rate.

${ }^{4}$ In theory, measures of Euro-zone productivity and demand (PROD*, DEMAND*) should be included in equation (5) as well. We will show that our chosen proxy for PROD actually is a relative productivity measure, so that PROD* is included. DEMAND* is not included on the assumption that most of the (joint) real exchange rate dynamics in the accession countries are determined by domestic rather than foreign developments.
} 
Overall, the empirical translation of equation (2), using the determinants of the internal and external exchange rate as specified in equations (4) and (5) respectively, looks as:

$$
Q_{t}=e_{0}+e_{1} C A_{t}+e_{2} D E B T_{t}+e_{3} O P E N+e_{4} P R O D_{t}+e_{5} D E M A N D_{t}+u_{t}
$$

It is this equation that we will estimate using a panel-cointegration approach in section 4. As the dependent variable, we use the level of the real exchange rate. Note that the transition from equation (2) to equation (6) implies a liniearization procedure. ${ }^{5}$

\section{Data and Empirical Methodology}

\subsection{Variables and data selection}

To empirically implement our exchange rate model, we first note that for most of the countries under consideration, it is impossible to find consistent data before 1993. Consequently, we have approximately 10 years of data. The use of quarterly data further constrains our selection process as a number of variables are only available at an annual frequency. If not stated differently, the data are collected from the IMF International Financial Statistics. ${ }^{6}$ Except for the indices, the data are originally expressed in millions of national currency. All time series are seasonally adjusted.

We define the productivity variable PROD for most countries as the ratio of industry production and industry employment relative to the same variable for the euro area as a whole. Only for Estonia - where the ratio of industry production and industry employment is unavailable - the ratio of GDP over total employment is used. In that case, GDP over total employment from the euro area is taken as benchmark. In this choice, we follow a large segment of the literature. ${ }^{7}$ In related research,

5 In the literature, a (semi-)logarithmic specification is often used with the logarithm of the real exchange rate as the dependent variable. We return to this issue in section 4.

6 The data are accessed via the IFS online service available at http://www.ifs.apdi.net/imf/logon.aspx.

7 The existing literature employs a wide variety of other proxy variables for productivity differentials, such as (relative) wages, relative consumer versus producer prices, total factor productivity, or measures of industry structure. Data availability typically precludes tests regarding the relevance of these variables. The exception 
output per capita is sometimes used as a measure of overall productivity in an economy (Smidkova et al. (2002), Lommatzsch and Tober (2002), Crespo Cuaresma et al. (2003), Frait and Komarek (2002), Dobrinsky (2001), MacDonald and Wojcik (2003)). However, in our view, output per capita is at best a second-best approach for productivity.

We define DEMAND as the ratio of private consumption expenditures over GDP. The advantage of this variable is its availability and consistent measurement across countries and time. Of course, it does not allow for the distinction between the demand for tradables and non-tradables. If possible, we would like a demand variable doing just that. In the recent literature, consumption, investment, government expenditures, and GDP variables have all been used to approximate demand pressures (See Égert and Lahrèche-Révil (2003), Frait and Komarek (2002), Filipozzi (2000), Kim and Korhonen (2002)). In particular, overall government expenditures or government consumption are often used as a proxy for demand pressure. We decided not to use these series for various reasons. First, government expenditures and government consumption are not consistently reported across countries. Second, over the transition period 1993-2003, most of the governments involved downsized substantially due to privatization and the switch from a centrally planned economy to a market economy. It is unclear how to interpret the government expenditure data in this respect. Finally, it is sometimes argued that the government deficit is a good proxy for demand pressures and that it is strongly related to the current account. Of course, the national income identity states that the current account equals the national savings surplus. This, in turn, equals the government surplus plus the private sector surplus. Since we already use both private consumption and the current account in the analysis, including the government deficit is inappropriate in our view. The three items together almost make up for the identity as only private investment is left out.

The current account (CA), expressed as a percentage of GDP, requires little explanation. It is reported in international databases as the difference between export and import of goods and services, taking also into account net income flows from international investment positions. Data on the external debt position (DEBT) of individual countries are typically very hard to come by. Availability

concerns the availability of data regarding the price ratio. However, our PROD measure is the preferred measure, as it is a more direct and exogenous measure of productivity than the price ratio. 
and consistency are low. Therefore, we use a proxy. We first compute the balance of a country's quarterly current account balance (CA) and the cumulated sum of the same country's quarterly net foreign direct investment (NFDI) flows. Minus the total value of this variable in a given quarter divided by GDP approximates the country's net foreign debt position. We motivate our approximation - in particular the role of NFDI - in the following way. Clearly, a country running a cumulated current account deficit for a number of periods needs external finance. One way to attract this finance is to borrow abroad and build up foreign debt. Thus, the link between cumulated current account balances and a country's net foreign asset position is straightforward. However, to the extent that the country succeeds in attracting net foreign direct investment from abroad, it needs less foreign debt. Of course, positive NFDI flows increase foreign claims on the country's assets. But these claims are proprietary claims, that is, foreigners become owners of some domestic assets or, alternatively, become shareholders in the country's future. The foreign owners are not entitled to specific payments but carry the risk of low returns on their assets. In our view, only the net debt position should be considered to play a role in the external equilibrium position as given in equation (3). For a related approach, we refer to Frait and Komarek (2002).

Finally, for openness (OPEN), we use the sum of exports and imports as a ratio of GDP. The use of this variable is quite standard in the literature as a proxy for increased international integration and a decline of tariff and non-tariff barriers. However, in a cross-section or panel approach, the same variable may also capture differences in size among the sampled countries as smaller countries tend to have higher import and export percentages in terms of GDP than larger ones. The empirical results with respect to the OPEN variable should therefore be interpreted with some caution.

Before we discuss the estimation method and the results, we elaborate on the procedure of the research. We estimate equation (6) in a panel framework. The result is a set of long-run coefficients that relate the selected fundamentals to the real exchange rate. To determine the long-run component of the value of the real exchange rate in a specific year, we multiply these coefficients by the actual value of the fundamentals in this year and add them up to form the estimated equilibrium real exchange rate. The deviation of the actual real exchange rate from the equilibrium real exchange rate 
is called a misalignment. ${ }^{8}$ Note that a misalignment implies that the exchange rate can be undervalued or overvalued. For the purpose of this research, measuring misalignments is important because it informs us about potential strains on the exchange rate and on the direction of the change in the exchange rate. $^{9}$

\subsection{Panel Cointegration}

We next turn to the econometric methodology. The analysis focuses on the determinants of the longrun real exchange rate level across countries. In the literature, several econometric methods have been used in order to estimate such Behavioural Equilibrium Exchange Rate (BEER). Basically, exchange rate developments have been analyzed via time-series (see Lommatzsch and Tober (2002), Coudert and Couharde (2002), Frait and Komarek (2002), Filipozzi (2000), Égert and Lahrèche-Révil (2003), inter alii) or panel-data methods (Kim and Korhonen (2002), Smidkova, Barrell, and Holland, (2002), Rahn (2003), De Broeck and Slok (2001), inter alii). In a time-series analysis, the database is a number of observations for one country over a specific time period. It allows one to estimate country-specific exchange rate developments. However, unbiased estimation results can only be reached if a sufficient number of data points is available. ${ }^{10}$

Unfortunately, for most of the accession countries this is not the case. Therefore panel-data analysis is used more often. This method increases the number of observations leading to unbiased estimators. However, the estimation results can only be interpreted as an 'average' estimator for the group of countries. Thus, the benefit of an extended database comes at the cost of a loss in countryspecific estimates.

In the context of long-run exchange rate determination, we have to take into account the problem of non-stationarity. Typically, real exchange rates as well as their determinants are nonstationary - that is, they lack a fixed mean value to which they tend to return over time - so that a

\footnotetext{
${ }^{8}$ Note that despite the simple definition, one major problem with the measurement of exchange rate misalignments is that exchange rate misalignments are not unambiguously defined. To measure exchange rate misalignments, one must define an equilibrium exchange rate, like a PPP rate or an equilibrium exchange rate (EER). From the discussion it will be clear that we have chosen to use an EER.

9 Note that in the misalignment literature it is assumed that exchange rates return to their equilibrium.

${ }^{10}$ The word 'sufficient' is deliberately vague because there is no rule for the minimum amount of observations.
} 
cointegration analysis is required. In a cross-country analysis, it leads to a panel-cointegration method. The use of normal OLS techniques will lead to spurious regression and specific panel cointegration techniques have to be used. Kao and Chen (1995) have shown that OLS in panel cointegrated models is asymptotically normal but nevertheless biased. Even the bias-corrected OLS estimator does not improve the OLS estimator in general (Chen, McCoskey, and Kao (1999)). Alternative methods are then necessary.

Phillips and Moon (2000) show that in the case of homogeneous and near-homogeneous panels ${ }^{11}$, the long-run coefficient can be obtained by a pooled fully modified (FM) estimator (see also Pedroni (2000)). This method is non-parametric as it employs kernel estimators of the nuisance parameters that affect the asymptotic distribution of the OLS estimator. It tackles the possible problem of endogeneity of the regressors as well as the autocorrelation of residuals. Kao and Chiang (2000) prefer to extend the work of Stock and Watson (1993) and Saikkonen (1991) and propose a pure panel dynamic least squares estimator (DOLS). This estimation procedure is parametric and has the advantage of computing convenience. In finite samples, it is shown by Kao and Chiang (2000) that the FM estimator does not improve over the OLS in general and the DOLS estimator appears to outperform the other methods especially if fixed effects are included. The DOLS estimator is thus the more promising method in the context of panel cointegration models. In our research we have therefore used the DOLS-estimator.

Practically, we consider the following panel regression:

$$
Y_{i, t}=\alpha+X_{i, t}{ }^{t} \beta+u_{i t},
$$

where $\mathrm{Y}_{\mathrm{i}, \mathrm{t}}$ and $\mathrm{X}_{\mathrm{i}, \mathrm{t}}$ are two integrated processes and $X^{t}$ stands for the transposed of $X$. We assume that each country shares an identical cointegration relationship (i.e., homogeneous panel hypothesis). $\mathrm{u}_{\mathrm{it}}$ are stationary residuals. The OLS estimator of $\beta$ is defined as

\footnotetext{
${ }^{11}$ In heterogeneous panel cointegration, each individual/country has its own specific cointegration relationship, while individuals/countries are assumed to have the same cointegration relationship in homogeneous panel cointegration. In near-homogeneous panel cointegration, individuals/countries have a slightly different cointegration relationship.
} 


$$
\hat{\beta}_{O L S}=\left[\sum_{i=1}^{N} \sum_{t=1}^{T}\left(X_{i, t}-\bar{X}_{i}\right)\left(X_{i, t}-\bar{X}_{i}\right)^{\prime}\right]^{-1}\left[\sum_{i=1}^{N} \sum_{t=1}^{T}\left(X_{i, t}-\bar{X}_{i}\right)\left(Y_{i, t}-\bar{Y}_{i}\right)\right],
$$

where $\bar{X}_{i}=(1 / T) \sum_{t=1}^{T} X_{i, t}$ and $\bar{Y}_{i}=(1 / T) \sum_{t=1}^{T} Y_{i, t}$.

A similar estimator applies when a fixed effect is introduced via a set $z_{i t}$ of deterministic dummy variables that is associated with each country i. Equation (7) then becomes

$$
Y_{i, t}=\alpha_{1}+X_{i, t}{ }^{t} \beta_{1}+z_{i, t}{ }^{\prime} \gamma_{1}+u_{i, t},
$$

where the OLS estimator of parameter vector $\left(\beta_{1}, \gamma_{1}\right)$ is given by equation (8) with $\beta=\left(\beta_{1}, \gamma_{1}\right)$. The ultimate DOLS estimator is derived using the following model:

$$
Y_{i, t}=\alpha+X_{i, t}{ }^{t} \beta+z_{i, t}{ }^{\prime} \gamma+\sum_{j=-p}^{p} c_{i, j} \Delta X_{i, t+j}+u_{i, t} .
$$

The p-order leads and lags are included to take into account the possible endogeneity and serial correlation of the errors and regressors, respectively. The coefficients are estimated by OLS and are unbiased. The model assumes long-run homogeneity (one cointegration relationship), but short-run heterogeneity. In all these models, the estimator of the variance-covariance matrix is in line with that of traditional OLS. Several panel cointegration tests have been proposed in this framework (Kao (1999) and Pedroni (2000)). Appendix 1 shortly reviews those associated with Kao (1999).

\section{Empirical Results}

In our approach, we follow Kao and Chiang (2000) and assume a homogeneous cointegration relationship across countries. That is, we assume that the coefficients to be estimated from equation (6) are the same for each country. Clearly, this is a heroic assumption as differences in economic 
structures, institutions, transition paths, and economic policies are very noticeable across these eight countries. On the other side, we have to acknowledge that the alternative of estimating an individual long-run relation between the real exchange rate of a country and five explanatory variables over a period as short as ten years requires heroic assumptions too. For this reason, we propose to estimate a joint cointegration relation across countries, even though statistical tests may literally reject the assumption of a common homogeneous cointegrating relation. Note that we do not necessarily want to maximize the explanatory power of the regression. Rather we would like to trace a robust fundamental relation between the real exchange rate and its determinants. Being able to combine the information in the economic development of more countries then becomes an advantage. Nevertheless, there is a trade-off. The more countries have diverging structures and experiences, the more hazardous becomes our assumption of a common cointegrating relation.

An additional caveat is in order here. The chosen methodology assumes that only one cointegrating relation exists among the set of variables. This need not be the case. In a time-series framework, methods - such as the Johansen-Juselius technique - exist to estimate and identify multiple cointegrating vectors in a set of variables. Unfortunately, similar methods are not yet available in a panel framework. To the extent that multiple cointegrating vectors exist, the estimated coefficients must be interpreted more cautiously, as they can reflect the interaction of more than one cointegrating relation.

To assess the robustness of our results, we therefore estimate a number of alternative specifications. Our first model - labeled TOTAL - uses a joint panel estimation for all eight accession countries. Based on both the difference in geographical position and in nominal and real exchange rate developments, we then split the total group of countries into two subgroups and re-estimate equation (6) for each of these two subgroups. On the one hand, we take the three Baltic countries - labeled BALTIC - and on the other hand the remaining five Central European countries - labeled CE. Secondly, we not only estimate the cointegrating relation for the full sample period 1993-2003, but also for the period 1995-2003. Clearly, the first two years in the sample were most hectic for these countries, as their transition process had just started. Estimating the panel over the shorter period allows an assessment of the impact of the first two relatively volatile years. 
Before we can apply such a panel-cointegration technique, we first need to establish the nonstationarity of both the real exchange rates series and the various explanatory variables. For this purpose, we use five different panel unit root tests. ${ }^{12}$ HT(1999) refers to a method used by Harris and Tzavalis (1999), LL(1992) represents the Levin and Lin (1992) approach, which gives two different statistics and, finally, IPS (1997) refers to Im-Pesaran-Shin (1997) for a unit root test with and without a time trend. The results are given in Table 1 . We only report p-values. A p-value below 0.05 suggests stationarity, while a p-value in excess of 0.05 suggests non-stationarity. Note that for each period and each choice of countries, a new set of unit root tests is required. In a number of cases, the tests yield conflicting results. Nevertheless, in an overall perspective, we conclude that the evidence typically points to non-stationarity of the real exchange rate (Q), productivity (PROD), openness (OPEN), and demand pressure (DEMAND). Especially for the current account (CA) and to a lesser extent for external debt (DEBT), the tests suggest stationarity. The implication is that the estimated coefficient on particularly the current account variable may not be interpretable as a structural long-run coefficient, but must be seen as representing part of the short-run dynamics around the long-run real exchange rate path.

Based on these panel unit root results, we decided to run another set of estimations using a reduced - parsimonious - form of equation (6). More specifically, we deleted the variables CA and DEBT from the specification of the three models (TOTAL, BALTIC, CE). Comparing the results for the parsimonious specification and the full model will give some insight into the robustness of the results as well.

\subsection{Estimated Equilibrium Real Exchange Rates}

We now turn to the results of our estimation. In Table 2 we present the results for the three groups of countries (TOTAL, BALTIC, CENTRAL EUROPEAN) and three periods/specifications. The full model over the full sample is indicated by (93-03), the full model over the shorter sample is indicated by (95-03), and the parsimonious model over the full sample is indicated by (93-03P). T-values are in parentheses below the estimated coefficients. The statistics $\operatorname{DF}(\rho), \operatorname{DF}(T), \operatorname{DF}^{*}(\rho)$, and $\operatorname{DF}^{*}(T)$ are

12 All computations are performed using NPT1.3 provided by Kao and Chiang (2000). http://www.maxwell.syr.edu/maxpages/faculty/cdkao/working/npt.html. 
tests for cointegration (see appendix 1). The null hypothesis is no cointegration. The estimated intercept and country-specific dummies are not reported in the table.

Overall, the results appear quite satisfactory. In each case, panel cointegration - that is, stationarity of the remaining residual - cannot be rejected at the 5 percent level. The (cross-section) explanatory power of the regression is quite high and coefficients are generally significant and have the predicted sign. More precisely, in all models and specifications, an increase in manufacturing (tradables) productivity in accession countries compared to the euro area leads to an appreciation of the accession country's currency. Especially when the Baltics are included in the model, the effect is sizable. The magnitude of the effects in the different specifications falls in the range reported by Égert (2003), which supports the plausibility of our findings. ${ }^{13}$

As hypothesized, the sign of the DEBT coefficient is negative and significant for the TOTAL specification. Higher external debt implies higher payment commitments to foreigners and thus a depreciated real exchange rate in order to be able to finance these payments through higher net exports. When the two subgroups are considered, the size of the DEBT coefficient decreases as well as its significance. For the CE group, the sign even reverses. Note again the possible panel stationarity of the DEBT variable, which may make the coefficient less interpretable.

A similar observation holds for the current account. We consistently find a negative coefficient, indicating that higher (appreciated) real exchange rates coincide with larger current account deficits. Clearly, this fits the facts as most countries over the period had high and rising current account deficits simultaneously with rising real exchange rates. It is unclear whether this can be interpreted as a long-run structural relation because of the econometric problem of the panel stationarity of the CA variable. Note that in all specifications, the current account effect is significantly reduced in size - and mostly significance too - when the shorter period starting in 1995 is considered.

\footnotetext{
${ }^{13}$ In line with some literature, we also estimated all models reported in Table 2 with the logarithm of the real exchange rate as dependent variable and the logarithm of productivity as one of the explanatory variables. The other variables were left unchanged. The resulting parameters change in size due to the data transformation. However, relative size, sign, and significance of the coefficients remain virtually unchanged. The same holds for the resulting under- and overvaluations of the different currencies. We therefore decided not to report the results, which are available on request from the authors.
} 
We find consistently positive and significant coefficients for the DEMAND variable. Actually, this result supports current thinking that trend like real appreciations of the internal real exchange rate may not come exclusively or even predominantly from the Balassa-Samuelson effect - which is of a supply-side nature -, but also from the demand side through a gradual shift towards expenditures on non-tradable goods and services. Finally, the OPEN coefficient is negative and quite large when the Baltic countries are included in the specification. For the Central-European countries on their own, a small positive effect is found, suggesting that these economies have been able to exploit European export markets more than the Baltics so far.

To further analyze the implications of the regression results in Table 2, we computed the time paths of the fundamental real exchange rates for each country under different specifications. They are graphically represented in Figure 1 (TOTAL), Figure 2 (BALTIC), and Figure 3 (CE). In the graphs, the line labeled REAL RATE is the actual real exchange rate normalized at unity in 1993:01. The lines labeled '93', '95', and '93P' represent the three different periods/specifications, respectively.

A number of points stand out. First, within each estimated model (TOTAL, BALTIC, CE) the estimated (fundamental) real exchange rate path is quite insensitive to either skipping the first 2 years of the sample or to removing CA and DEBT from the specification. The results thus appear reasonably robust against such changes. Second, the under- or overvaluation at the end of the sample period is not excessively large. Third, sizable swings have occurred in the past, but differences between the actual and the estimated fundamental exchange rate tend to disappear over time. Fourth, comparing the results for the Central European countries across models TOTAL and CE, the estimated fundamental exchange rates still look quite the same, though somewhat more heterogeneity can be observed than within models. The same holds true for the comparison of the evidence for the Baltics from the models TOTAL and BALTIC. Overall, we conclude that our results do not display excessive sensitivity to model specification and choice of estimation period. However, for a number of countries, the degree to which the fundamental exchange rate and the actual rate follow the same path is considerably less when the model is estimated for all countries together (TOTAL). It suggests that heterogeneity 
between the Baltic states on the one hand and the Central European countries on the other may warrant the use of separate estimations (BALTIC versus CE). ${ }^{14}$

\subsection{Misalignments}

So far we have looked at the estimated fundamental exchange rate level directly and compared it to the actual real exchange rate. Now we turn to the difference between the actual and fundamental real exchange rate, which is our measure of the estimated under- or overvaluation. That is, for each country we compute the time series of estimated under- or overvaluation. Ideally, we would prefer all models to give the same verdict on overvaluation or undervaluation each quarter. In Table 3, we provide additional evidence on this issue by giving the matrix of bilateral correlation coefficients of measured undervaluation and overvaluation across models and specifications per country.

For a better understanding, we will elaborate on the results for the Czech Republic. In the correlation matrix for the Czech Republic, the upper left triangle contains the correlations of the three undervaluation measures based on the three specifications of the model for all eight countries (TOTAL). The correlation between the 93-03 and 95-03 results is quite high at 0.85 . The correlation between each of these and the 93-03P model is lower and slightly above 0.50 . The lower right triangle gives the same information for the three specifications of the estimated CE model, using the five Central European countries only. Now all correlations are very high, the lowest one being equal to 0.93. In the lower left 3 by 3 matrix are the cross-model correlation coefficients, which happen to be quite volatile. While the correlation between all three CE-specifications and Total 93-03P is around 0.50, the other cross-correlations are negative. More or less the same picture arises for the other Central-European countries. Typically, the bilateral correlation coefficients based on one model are high - all higher than for the Czech Republic, while the cross-model correlation coefficients are lower and volatile. For the three Baltic countries, not only the within model correlations, but also the crossmodel correlations are very high.

\footnotetext{
${ }^{14}$ It is sometimes argued that Slovenia is structurally different from the other Central European countries. To test whether the inclusion of Slovenia influences the results for our $C E$ model, we also estimated the model for the Czech Republic, Hungary, Poland, and Slovakia only. The results were only marginally different from the five-country $C E$ model. We therefore decided not to report the results. However, they are available on request from the authors.
} 
Overall, the results suggest that at least for some countries, the apparent heterogeneity between the Baltic countries on the one hand and the Central European countries on the other is important enough to warrant use of the two smaller models (BALTIC, CE) rather than one common model (TOTAL).

In Table 4, we consider the evidence on overvaluation or undervaluation for each country using the most recent period in our sample, the second quarter of 2003. For each country we present the estimated misalignment in 2003:2 as a percentage of the underlying fundamental real exchange rate at that time. Using all models, we have six estimates per country. A negative number implies an undervaluation, while a positive one indicates an overvaluation. According to Table 4, the different model specifications tend to give the same answer to the question of whether a specific currency was overvalued or undervalued in 2003:2. The exceptions are Slovenia and to a lesser extent the Czech Republic. With respect to Slovenia, the overall model (TOTAL) typically reports evidence of a considerable undervaluation, while the central European model (CE) gives a marginal overvaluation. For the Czech Republic, the TOTAL specification yields an undervaluation in two out of three cases, whereas the CE model consistently shows an overvaluation. For the other countries, at most one of the assessments of under- or overvaluation is out of line. In each case it concerns one out of the three specifications of the TOTAL model. Since we already concluded that the heterogeneity between the central European countries and the Baltic countries renders the overall model probably less reliable than the two submodels, we pay more attention to the submodel results, which are in the upper three rows of the table.

Then, our results suggest that especially Poland is significantly undervalued in 2003:2. This result is probably mainly attributable to the large nominal exchange rate depreciation over the previous two years. Prior to that, the zloty was typically overvalued. The currencies of the Czech Republic (about 14 percent), Slovakia (about 19 percent), Estonia (about 7 percent), and Hungary (about 5 percent) are overvalued. For Latvia and Lithuania we document small undervaluations (around 3 percent) in 2003.

The bottom panel of Table 4 reports the standard deviations of the misalignments over the sample period 1995-2003. Note that the size of the standard deviation of the misalignment differs 
considerably across these same countries. In most countries, the reported misalignment in 2003 is less than one standard deviation away from zero. That is, given the uncertainty about the estimated level of the fundamental exchange rate, the estimated misalignments are small enough to be insignificantly different from zero. The overvaluations of the Czech Republic and Slovakia - and to a lesser extent the undervaluation of Poland - are around 1.5 times the standard deviation and, thus, statistically more significant.

To investigate how fast misalignments are corrected, we estimate the extent to which the actual real exchange rate moves back in the direction of the fundamental in the next quarter. In Table 5, we present the panel estimation of the corresponding error-correction model. Theoretically, the model could be extended to include other determinants of real exchange rate dynamics such as real interest rate differentials. Here, we confine the analysis to a simple regression of the change in the real exchange rate on the lagged value of the misalignment.

The results are typical for this type of regression. The coefficient on the lagged misalignment variable is consistently negative and significant. This result is in line with the predictions of a cointegrated framework that stipulates the elimination of deviations of the real exchange rate from its equilibrium value. However, the size of the effects is small, suggesting that in a given quarter at the minimum 2.6 percent (TOTAL, 95-03) and at the maximum 8.4 percent (CE, 95-03) of the prevailing misalignment is eliminated. The observed slow speed of adjustment is often found in empirical real exchange rate analysis.

\section{Conclusion}

In this paper, we have estimated fundamental bilateral real exchange rates for a set of eight accession countries using a panel-cointegration approach over the period 1993-2003. Given the difference between the Baltic States and the Central European countries, we have estimated the model for eight accession countries, for the three Baltic States separately, and for the five Central European Countries separately. We have not estimated the Balassa-Samuelson (BS) effect separately, but the estimated 
coefficient on the productivity variable is quite significant in all estimates, in particular for the Baltic States. An increase in productivity in the tradables sector does indeed lead to an appreciation of the real exchange rate. Concerning the estimated misalignments, the results are robust and generally in line with the literature; we find an overvaluation around 15 percent for the Czech Republic and Slovakia and an overvaluation of about 5 percent for Hungary. For Slovenia, we hardly find any misalignment, as documented by others too. If anything, there is a small overvaluation. For Poland, we report an undervaluation of approximately 10-15 percent in 2003. According to our estimates, the zloty was indeed substantially overvalued around 2001 as suggested by the literature. However, the subsequent strong nominal depreciation has even overshot the fundamental exchange rate, so that now an undervaluation exists. With respect to the Baltic countries, no empirical results could be found in the literature with respect to Latvia and Lithuania. We report a small undervaluation for both countries. For Estonia, we find an overvaluation of about 7 percent in 2003. In the literature, small overvaluations are reported for Estonia in 2001-2002 as well.

From these results, several policy recommendations can be drawn. First, our research shows steadily appreciating real exchange rates for all countries under consideration and documents a significant positive link between productivity levels and the corresponding real exchange rate levels. Moreover, future rises in productivity cannot be excluded on the basis of either our own analysis or the literature as a whole. Consequently, inflation pressure and real exchange rate appreciation in the accession countries probably remain a fact of life in the near future.

Second, the extent to which this is a problem for a fixed nominal exchange rate regime is hard to determine. From the evidence over the past decade, we know that the link between nominal and real exchange rate variability is quite weak. For instance, in Slovakia the nominal exchange rate has been reasonably stable since 1999, while the real exchange rate appreciated considerably over the same period. The same holds true for Hungary. Slovenia experienced a rather stable real exchange rate and a nominal depreciation. Apparently, price dynamics in the accession countries are still quite flexible to accommodate substantial real exchange rate movements even when the nominal exchange rate is rather fixed. Moreover, we do expect real exchange rate appreciations to be more modest in the future than they were in the early nineties. 
Third, our results suggest that a real appreciation mostly originates from movements in the internal real exchange rate. Particularly relative productivity and the demand variable are the most significant in our regression results. The determinants of the external real exchange rate play a less dominant role. We do not have independent evidence on the validity of PPP for tradable goods. Overall, the evidence suggests less of an issue on the tradable side than on the non-tradable side. It implies that price adjustment is mostly an internal process for the accession countries.

Overall, the above three observations suggest that a fixed exchange rate regime for each of the accession countries would be feasible in itself, despite possible future real exchange rate appreciations due to either the BS effect or demand shifts. Because it seems that the BS effect is not very large in most countries (as Balcerowicz claims (2002, p. 68), it is a 'manageable' effect) and the inflation in new member state countries is not much higher than that of Spain and Portugal when they joined the EMS (for example for 2001 both the Czech and the Polish inflation was lower than the inflation in Spain and in Portugal in 1994), the research results suggest that indeed "the Accession countries should not experience more problems of convergence than the present Euro-members prior to their entry into the monetary union" (De Grauwe, 2002, p. 61). With respect to the appropriate level of a parity exchange rate against the euro, we find that the magnitude of misalignments was limited in the middle of 2003 and fell within the range of 1 standard deviation of the average real exchange rate over the past 10 years. In that sense, prevailing market exchange rates (at least in 2003) appear to give a reasonable indication of the level at which a parity exchange rate should be approximately set. 


\section{References}

Balcerowicz, L. (2002), The way to EMU from a candidate country's perspective, CESIfo Forum, Summer 2002, p. 68-71.

Chen, B., S. McCoskey, and C. Kao (1999), Estimation and inference of a cointegrated regression in panel data: A Monte-Carlo study, American Journal of Mathematical and Management Sciences, 19, 75-114.

Coudert, V., \& Couharde, C. (2002), Exchange rate regimes and sustainable parities for CEECs in the run-up to EMU membership, CEPII working paper No 2002-15.

Crespo-Cuaresma, J., Fidrmuc, J., and MacDonald, R. (2003), The monetary approach to exchange rates in the CEECs, Bank of Estonia working paper No. 14.

De Broeck, M., \& Slok, T. (2001), Interpreting real exchange rate movements in transition countries, IMF working paper WP/01/56.

De Grauwe, P. (2002), The Euro at stake? The monetary union in an enlarged Europe, CESIfo Forum, Summer 2002, p. 58-61.

Dobrinsky, R. (2001), Convergence in per capita income levels, productivity dynamics and real exchange rates in the candidate countries on the way to EU accession, International Institute for Applied Systems Analysis, Interim Report No. 38.

Égert, B. (2003), Assessing equilibrium real exchange rates in accession countries: Can we have DEER with BEER without FEER?, forthcoming in Focus on Transition.

Égert, B., \& Lahrèche-Révil, A. (2003), Estimating the fundamental equilibrium exchange rate of Central and Eastern European countries: The EMU enlargement perspective, CEPII working paper No 2003-05.

Filipozzi, F. (2000), Equilibrium exchange rate of the Estonian Kroon, its dynamics and impacts of deviations, Working paper, Eesti Bank, 3.

Frait, J., and Komárek, L. (2002), Theoretical and empirical analysis of the debt-adjusted real exchange rate in selected transition economies during 1994-2001, Warwick economic research papers No 646.

Harris, R.D.F. and Tzavalis, E. (1999), Inference for unit roots in dynamic panel when the time dimension is fixed, Journal of Econometrics, 91, 201-226.

Im, K.S, M.H. Pesaran and Y. Shin (1997), Testing for unit roots in heterogeneous panels, Manuscript Department of Applied Economics, University of Cambridge.

Kao, C. (1999), Spurious regression and residual-based tests for cointegration in panel data, Journal of Econometrics, 90, 1-44.

Kao, C. and M.H., Chiang (2000), On the estimation and inference of a cointegrated regression in panel data, Advances in Econometrics, 15, 179-202. 
Kim, B.-Y., \& Korhonen, L. (2002), Equilibrium exchange rates in transition countries: Evidence from dynamic heterogeneous panel models, BOFIT discussion papers 15/2002.

Levin, A. and C.F. Lin (1992), Unit root test in panel data: Asymptotic and finite sample properties, Discussion Paper 92-93 UCDS.

Lommatzsch, K., \& Tober, S. (2002), What is behind the real appreciation of the accession countries' currencies? An investigation of the PPI based real exchange rate, Paper presented at "Exchange rate strategies during the EU Enlargement, Budapest", 27-30 November. www.icegec.hu

MacDonald, R (2000), Concepts to calculate equilibrium exchange rates: An overview, Discussion Paper 3/00, Deutsche Bundesbank.

MacDonald, R., \& Wójcik, C. (2003), Catching up: The role of demand, supply and regulated price effects on the real exchange rates of four accession countries, Munich: CESifo working paper No. 899.

Pedroni, P. (2000), Fully modified OLS for heterogeneous panels, Advances in Econometrics, 15, 93130.

Phillips, P.C.B. and H., Moon (2000) Nonstationary panel data analysis: An overview of some recent developments, Econometric Reviews, 19, 263-286.

Rahn, J. (2003), Bilateral equilibrium exchange rates of EU accession countries against the euro, BOFIT discussion papers 11/2003.

Saikkonen, P. (1991), Asymptotically efficient estimation of cointegrating regressions, Econometric Theory, 58, 1-21.

Šmídková, K., Barrell,R., \& Holland,D. (2002), Estimates of fundamental real exchange rates for the five EU pre-accession countries, Working Paper 3. Prague: Czech National Bank.

Stock, J. and M. Watson, (1993), A simple estimator of cointegrating vector in higher order integrated systems, Econometrica, 61, 783-820. 


\section{Appendix 1}

Kao (1999) proposes a panel cointegration test based on Dickey-Fuller statistics (DF). Let us consider the following model:

$Y_{i, t}=\alpha+X_{i, t}{ }^{t} \beta+u_{i t}$,

where $X_{i, t}=X_{i, t-1}+\varepsilon_{i t}$ and $u_{i t}$ is $\mathrm{I}(1)$. The test can be calculated from the estimated residuals $\hat{u}_{i, t}=\rho \hat{u}_{i, t-1}+v_{i t}$ where $\hat{u}_{i, t}=Y_{i, t}-X{ }^{t}{ }_{i t} \hat{\beta}$. The cointegration hypothesis is thus $H_{0}: \rho=1$. The OLS estimate of $\rho$ and its associated t-stat $\left(\mathrm{t}_{\rho}\right)$ are the following ones:

$\hat{\rho}=\frac{\sum_{i=1}^{N} \sum_{t=2}^{T} \hat{u}_{i, t} \hat{u}_{i, t-1}}{\sum_{i=1}^{N} \sum_{t=2}^{T} \hat{u}^{2}{ }_{i, t}} \quad$ and $\quad t_{\hat{\rho}}=\frac{(\hat{\rho}-1) \sqrt{\sum_{i=1}^{N} \sum_{t=2}^{T} \hat{u}_{i, t-1}^{2}}}{\sqrt{(1 / N T) \sum_{i=1}^{N} \sum_{i=2}^{T}\left(\hat{u}_{i, t}-\hat{\rho} \hat{u}_{i, t-1}\right)^{2}}}$.

Kao (1999) proposed 4 cointegration tests:

$$
\begin{aligned}
& D F_{\rho}=\frac{\sqrt{N} T(\hat{\rho}-1)+3 \sqrt{N}}{\sqrt{10.2}}, \quad D F_{T}=\sqrt{1.25} t_{\hat{\rho}}+\sqrt{1.875 N}, \quad D F_{T}^{*}=\frac{t_{\rho}+\frac{\sqrt{6 N} \hat{\sigma}_{v}}{2 \hat{\sigma}_{0 v}{ }^{2}}}{\sqrt{\frac{3 \hat{\sigma}_{v}{ }^{2}}{10 \hat{\sigma}_{0 v}{ }^{2}}+\frac{\hat{\sigma}_{0 v}{ }^{2}}{2 \hat{\sigma}_{v}{ }^{2}}}} \text { and, } \\
& D F_{\rho}^{*}=\frac{\sqrt{N} T(\hat{\rho}-1)+\frac{3 \sqrt{N} \hat{\sigma}_{v}{ }^{2}}{\hat{\sigma}_{0 v}{ }^{2}}}{\sqrt{3+\frac{36 \hat{\sigma}_{v}{ }^{4}}{5 \hat{\sigma}_{0 v}{ }^{4}}}},
\end{aligned}
$$

where $\hat{\sigma}^{2}{ }_{v}=\Sigma_{u}-\Sigma_{u \varepsilon} \Sigma^{-1}{ }_{\varepsilon}$ and $\hat{\sigma}^{2}{ }_{0 v}=\Omega_{u}-\Omega_{u \varepsilon} \Omega^{-1}{ }_{\varepsilon}, \Sigma$ being the variance-covariance matrix, and $\Omega$ the long-run variance-covariance matrix. Similarly, Augmented DF tests can be built. 
Table 1 Panel-Unit Root Tests (p-values)

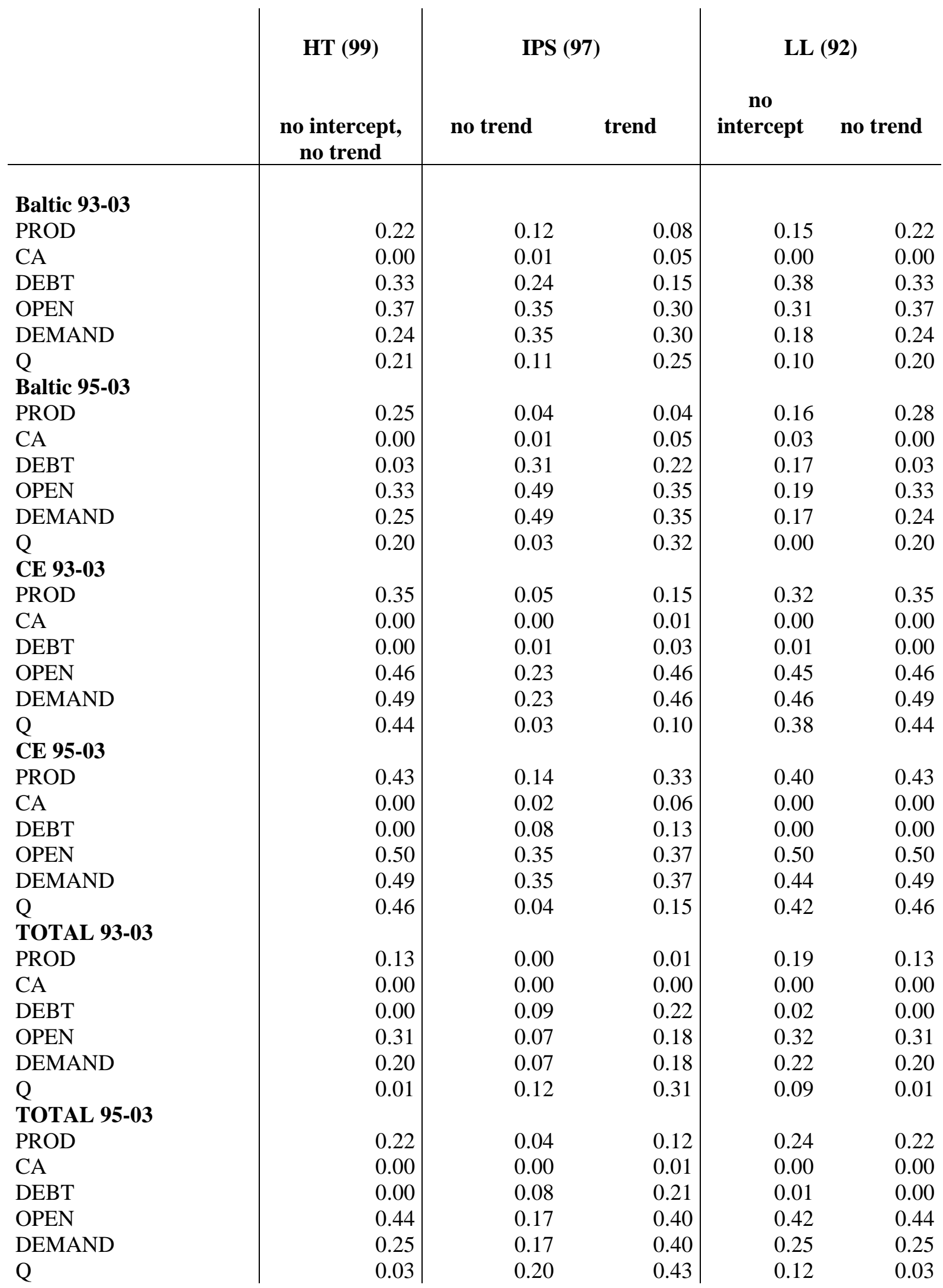


Table 2 Regression Results

\begin{tabular}{|c|c|c|c|c|c|c|c|c|c|}
\hline & \multicolumn{3}{|c|}{ TOTAL } & \multicolumn{3}{|c|}{ BALTIC } & \multicolumn{3}{|c|}{ CENTRAL EUROPEAN } \\
\hline & 93-03 & 95-03 & 93-03P & 93-03 & 95-03 & 93-03P & 93-03 & $95-03$ & 93-03P \\
\hline PROD & $\begin{array}{c}2.35 \\
(28.44)\end{array}$ & $\begin{array}{c}2.25 \\
(28.01)\end{array}$ & $\begin{array}{c}2.95 \\
(30.33)\end{array}$ & $\begin{array}{c}2.44 \\
(19.85)\end{array}$ & $\begin{array}{c}1.95 \\
(14.43)\end{array}$ & $\begin{array}{c}2.63 \\
(21.86)\end{array}$ & $\begin{array}{c}0.37 \\
(7.09)\end{array}$ & $\begin{array}{c}0.52 \\
(9.12)\end{array}$ & $\begin{array}{c}0.33 \\
(5.23)\end{array}$ \\
\hline CA & $\begin{array}{c}-3.62 \\
(17.55)\end{array}$ & $\begin{array}{c}0.20 \\
(0.79)\end{array}$ & - & $\begin{array}{l}-1.07 \\
(2.87)\end{array}$ & $\begin{array}{l}-0.40 \\
(0.63)\end{array}$ & - & $\begin{array}{c}-2.15 \\
(20.97)\end{array}$ & $\begin{array}{l}-0.47 \\
(4.09)\end{array}$ & - \\
\hline DEBT & $\begin{array}{c}-0.52 \\
(10.76)\end{array}$ & $\begin{array}{l}-0.40 \\
(8.92)\end{array}$ & - & $\begin{array}{l}-0.08 \\
(0.78)\end{array}$ & $\begin{array}{l}-0.21 \\
(1.62)\end{array}$ & - & $\begin{array}{c}0.03 \\
(1.52)\end{array}$ & $\begin{array}{c}0.08 \\
(3.68)\end{array}$ & - \\
\hline OPEN & $\begin{array}{c}-1.33 \\
(19.24)\end{array}$ & $\begin{array}{l}-0.73 \\
(9.30)\end{array}$ & $\begin{array}{c}-1.73 \\
(21.24)\end{array}$ & $\begin{array}{c}-2.05 \\
(20.42)\end{array}$ & $\begin{array}{c}-1.79 \\
(10.20)\end{array}$ & $\begin{array}{c}-2.17 \\
(19.96)\end{array}$ & $\begin{array}{c}0.17 \\
(3.82)\end{array}$ & $\begin{array}{c}0.16 \\
(3.86)\end{array}$ & $\begin{array}{c}0.29 \\
(5.21)\end{array}$ \\
\hline DEMAND & $\begin{array}{c}0.36 \\
(2.25)\end{array}$ & $\begin{array}{c}0.54 \\
(3.98)\end{array}$ & $\begin{array}{c}1.16 \\
(6.18)\end{array}$ & $\begin{array}{c}1.78 \\
(9.84)\end{array}$ & $\begin{array}{c}1.27 \\
(6.83)\end{array}$ & $\begin{array}{c}2.20 \\
(11.36)\end{array}$ & $\begin{array}{c}0.88 \\
(3.85)\end{array}$ & $\begin{array}{c}1.96 \\
(7.01)\end{array}$ & $\begin{array}{c}0.97 \\
(3.41)\end{array}$ \\
\hline $\mathbf{R}^{2}$ & 0.958 & 0.979 & 0.941 & 0.968 & 0.971 & 0.967 & 0.781 & 0.822 & 0.691 \\
\hline $\mathbf{D F}(\rho)$ & -21.36 & -18.14 & -21.45 & -11.77 & -7.26 & -12.81 & -9.53 & -10.56 & -5.40 \\
\hline DF(T) & -5.69 & -5.18 & -5.74 & -4.23 & -2.94 & -4.55 & -3.36 & -3.67 & -2.40 \\
\hline $\mathrm{DF}^{*}(\rho)$ & -36.82 & -31.21 & -36.96 & -18.32 & -11.52 & -20.51 & -16.26 & -17.60 & -10.25 \\
\hline $\mathrm{DF}^{*}(\mathrm{~T})$ & -4.26 & -3.97 & -4.30 & -3.79 & -2.76 & -3.94 & -2.87 & -3.16 & -2.00 \\
\hline
\end{tabular}




\section{Estonia}

Total 93-03

Total 95-03

Total 93-03 P

Baltic 93-03

Baltic 95-03

Baltic 93-03 P
|

Total 93-03 Total 95-03

1.00

0.83

0.90

0.93

0.91

0.90
1.00

0.85

0.85

0.92

0.85
Totas

Total 93-03 P

1.00

0.98

0.95

0.99

Baltic 93-03Baltic 95-03Baltic 93-03 P

\section{Latvia}

Total 93-03

Total 95-03

Total 93-03 P

Baltic 93-03

Baltic 95-03

Baltic 93-03 P

Total 93-03 Total 95-03

1,00

0.97

0.76

0.88

0.95

0.81

1.00

0.77

0.88

0.97

0.83

\begin{tabular}{l|l}
0.98 \\
0.99
\end{tabular}

1.00

0.98

1.00

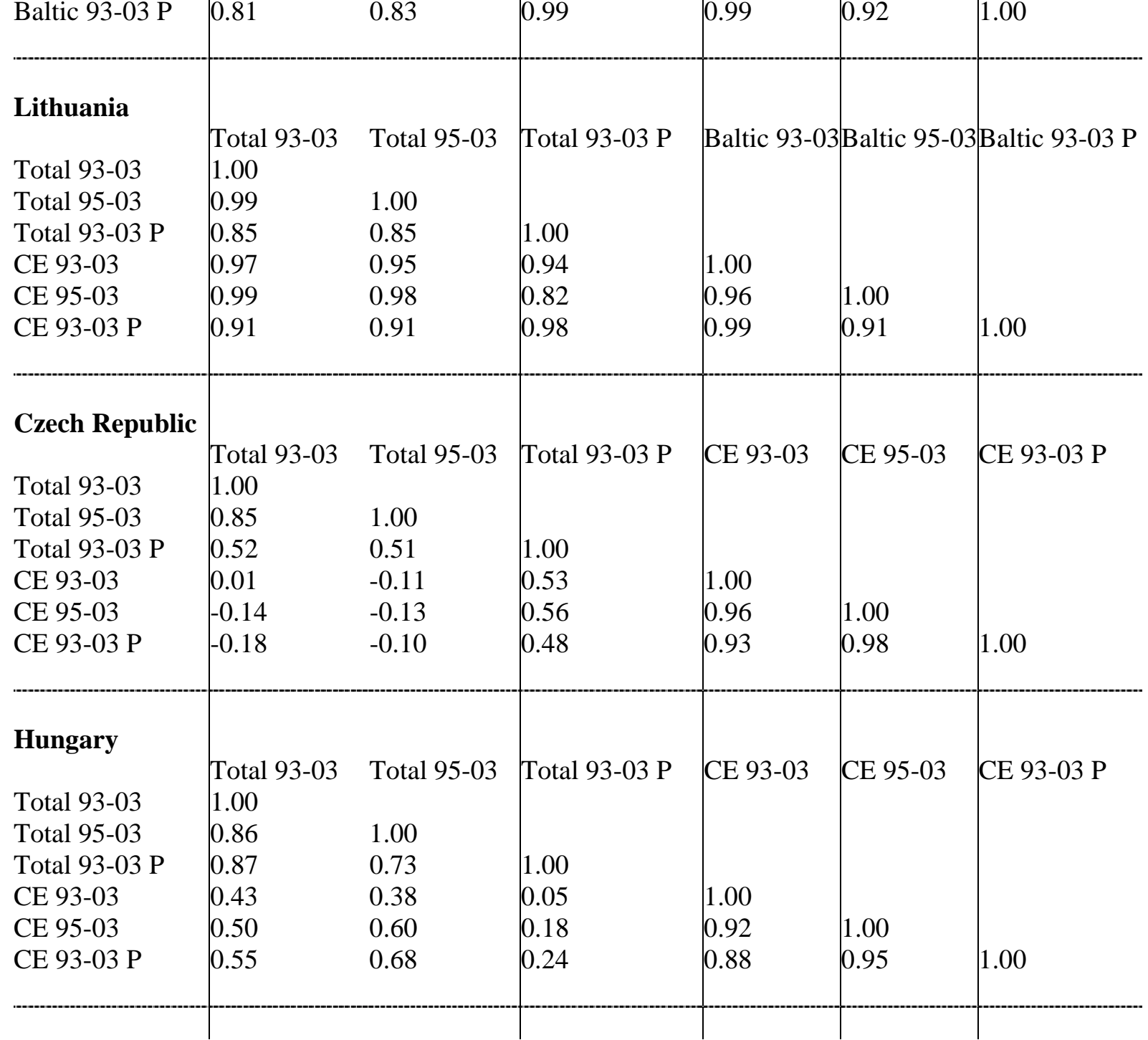




\begin{tabular}{|c|c|c|c|c|c|c|}
\hline Poland & & & & & & \\
\hline Total 93-03 & $\begin{array}{l}\text { Total 93-03 } \\
1.00\end{array}$ & Total 95-03 & Total 93-03 P & CE 93-03 & CE 95-03 & CE 93-03 P \\
\hline Total 95-03 & 0.97 & 1.00 & & & & \\
\hline Total 93-03 P & 0.96 & 0.99 & 1.00 & & & \\
\hline CE 93-03 & 0.38 & 0.31 & 0.18 & 1.00 & & \\
\hline CE 95-03 & 0.57 & 0.58 & 0.45 & 0.92 & 1.00 & \\
\hline CE 93-03 P & 0.14 & 0.15 & 0.00 & 0.91 & 0.88 & 1.00 \\
\hline Slovenia & & & & & & \\
\hline Total 93-03 & $\begin{array}{l}\text { Total 93-03 } \\
1.00\end{array}$ & Total 95-03 & Total 93-03 P & CE 93-03 & CE 95-03 & CE 93-03 P \\
\hline Total 95-03 & 0.82 & 1.00 & & & & \\
\hline Total 93-03 P & 0.82 & 0.93 & 1.00 & & & \\
\hline CE 93-03 & 0.14 & -0.38 & -0.25 & 1.00 & & \\
\hline CE 95-03 & -0.26 & -0.34 & -0.27 & 0.58 & 1.00 & \\
\hline CE 93-03 P & -0.32 & -0.13 & -0.22 & 0.17 & 0.81 & 1.00 \\
\hline Slovakia & & & & & & \\
\hline Total 93-03 & $\begin{array}{l}\text { Total 93-03 } \\
1.00\end{array}$ & Total 95-03 & Total 93-03 P & CE 93-03 & CE 95-03 & CE 93-03 P \\
\hline Total 95-03 & 0.83 & 1.00 & & & & \\
\hline Total 93-03 P & 0.76 & 0.86 & 1.00 & & & \\
\hline CE 93-03 & 0.34 & -0.16 & -0.02 & 1.00 & & \\
\hline CE 95-03 & 0.06 & -0.16 & 0.08 & 0.77 & 1.00 & \\
\hline CE 93-03 P & 0.45 & 0.40 & 0.54 & 0.55 & 0.79 & 1.00 \\
\hline
\end{tabular}


Table $4 \quad$ Estimated Misalignments in 2003:2

Misalignment (\%, 2003:2)

Baltic CE 93-03

Baltic CE 95-03

Baltic CE 93-03P

Total 93-03

Total 95-03

Total 93-03P

EST LAT LIT CZE HUN POL SLV SVK

$\begin{array}{llllllll}7.76 & -3.34 & -3.70 & 14.48 & 4.42 & -10.12 & 3.82 & 18.88\end{array}$

$\begin{array}{llllllll}6.12 & -1.24 & -2.41 & 12.94 & 3.54 & -16.28 & 2.94 & 11.42\end{array}$

$\begin{array}{llllllll}8.59 & -3.97 & -6.00 & 14.62 & 6.59 & -11.18 & 3.61 & 13.50\end{array}$

$\begin{array}{llllllll}5.19 & 1.87 & 0.27 & -14.34 & 11.76 & -38.50 & -24.64 & 17.34\end{array}$

$\begin{array}{llllllll}8.15 & 0.77 & -4.03 & -13.73 & 27.25 & -37.45 & -20.07 & -2.71\end{array}$

$\begin{array}{llllllll}4.73 & -6.17 & -8.72 & 4.19 & -0.90 & -47.63 & -21.53 & 18.07\end{array}$

Standard deviation of the misalignment (\%, 1995:1-2003:2)

Baltic CE 93-03

Baltic CE 95-03

Baltic CE 93-03P

Total 93-03

Total 95-03

$\begin{array}{llllllll}\text { EST } & \text { LAT } & \text { LIT } & \text { CZE } & \text { HUN } & \text { POL } & \text { SLV } & \text { SVK } \\ & & & & & & & \\ 16.11 & 9.89 & 11.80 & 9.77 & 8.77 & 8.84 & 4.31 & 9.19 \\ 14.68 & 11.56 & 12.89 & 9.98 & 7.53 & 8.49 & 2.74 & 4.94 \\ 16.01 & 10.02 & 11.20 & 8.89 & 8.08 & 8.69 & 2.22 & 5.17 \\ 12.25 & 12.05 & 14.74 & 13.85 & 18.85 & 33.37 & 11.88 & 27.10 \\ 9.26 & 13.16 & 13.35 & 8.57 & 49.41 & 42.44 & 11.66 & 17.61 \\ 10.59 & 9.38 & 11.10 & 24.04 & 16.68 & 68.74 & 13.94 & 19.22\end{array}$


Table 5 Panel Error-Correction Results

\begin{tabular}{|c|c|c|c|c|c|c|c|c|c|}
\hline & \multicolumn{3}{|c|}{ Total } & \multicolumn{3}{|c|}{ Baltic } & \multicolumn{3}{|c|}{ Central European } \\
\hline & $95-03$ & $93-03$ & 93-03 P & $95-03$ & $93-03$ & 93-03 P & $95-03$ & $93-03$ & 93-03 P \\
\hline Constant & $\begin{array}{l}0.012^{*} \\
(6.236)\end{array}$ & $\begin{array}{l}0.018^{*} \\
(7.856)\end{array}$ & $\begin{array}{l}0.018^{*} \\
(7.736)\end{array}$ & $\begin{array}{l}0.017^{*} \\
(5.600)\end{array}$ & $\begin{array}{l}0.034^{*} \\
(7.728)\end{array}$ & $\begin{array}{l}0.034^{*} \\
(7.704)\end{array}$ & $\begin{array}{l}0.008^{*} \\
(3.572)\end{array}$ & $\begin{array}{l}0.007^{*} \\
(3.727)\end{array}$ & $\begin{array}{l}0.007^{*} \\
(3.795)\end{array}$ \\
\hline $\begin{array}{l}\text { Misalignment } \\
(\mathrm{t}-1)\end{array}$ & $\begin{array}{l}-0.026^{*} \\
(-4.638)\end{array}$ & $\begin{array}{l}-0.045^{*} \\
(-9.446)\end{array}$ & $\begin{array}{l}-0.044 * \\
(-8.374)\end{array}$ & $\begin{array}{l}-0.028^{*} \\
(-4.560)\end{array}$ & $\begin{array}{l}-0.062 * \\
(-8.371)\end{array}$ & $\begin{array}{l}-0.063^{*} \\
(-8.240)\end{array}$ & $\begin{array}{l}-0.084^{*} \\
(-3.351)\end{array}$ & $\begin{array}{l}-.042^{* *} \\
(-2.275)\end{array}$ & $\begin{array}{l}-0.064^{*} \\
(-3.782)\end{array}$ \\
\hline $\begin{array}{l}\mathrm{N} \\
\text { Adjusted } \mathrm{R}^{2}\end{array}$ & $\begin{array}{c}272 \\
0.070\end{array}$ & $\begin{array}{c}328 \\
0.213\end{array}$ & $\begin{array}{c}328 \\
0.174\end{array}$ & $\begin{array}{c}102 \\
0.164\end{array}$ & $\begin{array}{c}123 \\
0.362\end{array}$ & $\begin{array}{c}123 \\
0.354\end{array}$ & $\begin{array}{c}170 \\
0.057\end{array}$ & $\begin{array}{c}205 \\
0.020\end{array}$ & $\begin{array}{c}205 \\
0.061\end{array}$ \\
\hline F-Statistic & $21.511^{*}$ & $89.236^{*}$ & $70.116^{*}$ & $20.788 *$ & $70.081^{*}$ & $67.901^{*}$ & $11.228 *$ & $5.174^{* *}$ & $14.303^{*}$ \\
\hline
\end{tabular}

Note: The t-statistics are in parentheses. $*, * *$ denote the significance at the one and five percent level, respectively. 
Figure 1 Actual and Estimated Real Exchange Rates (TOTAL)
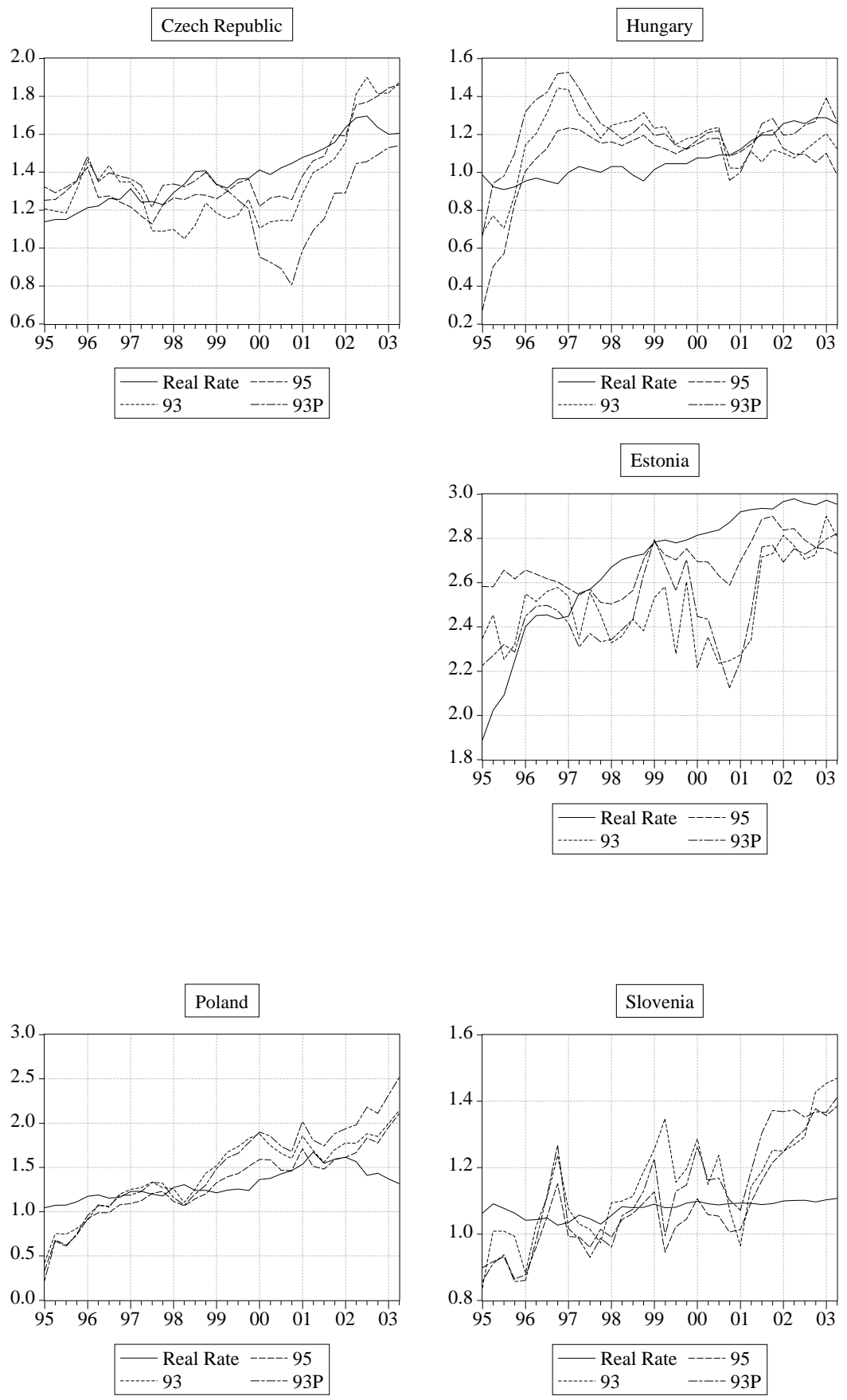

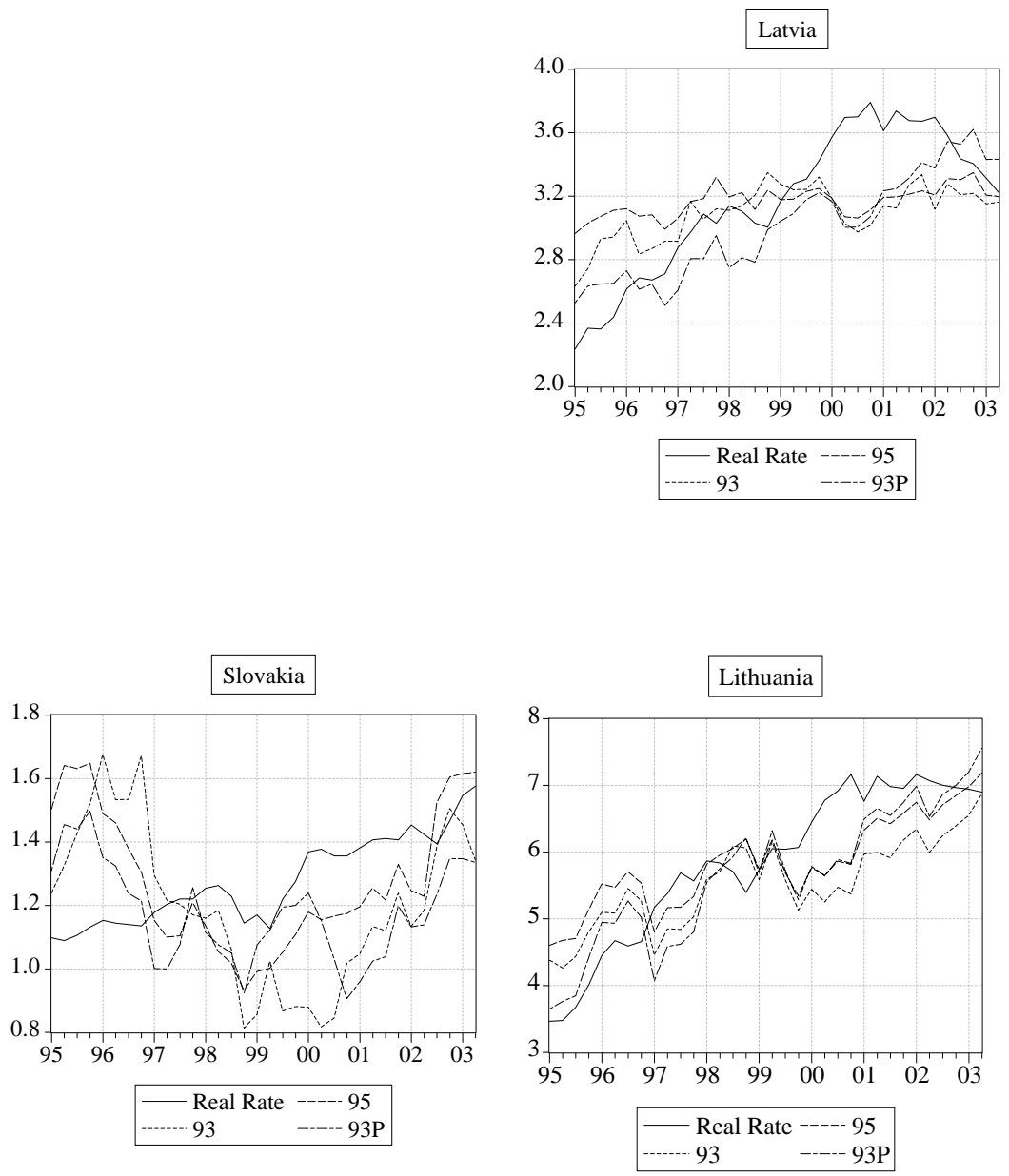
Figure 2 Actual and Estimated Real Exchange Rates (BALTIC)
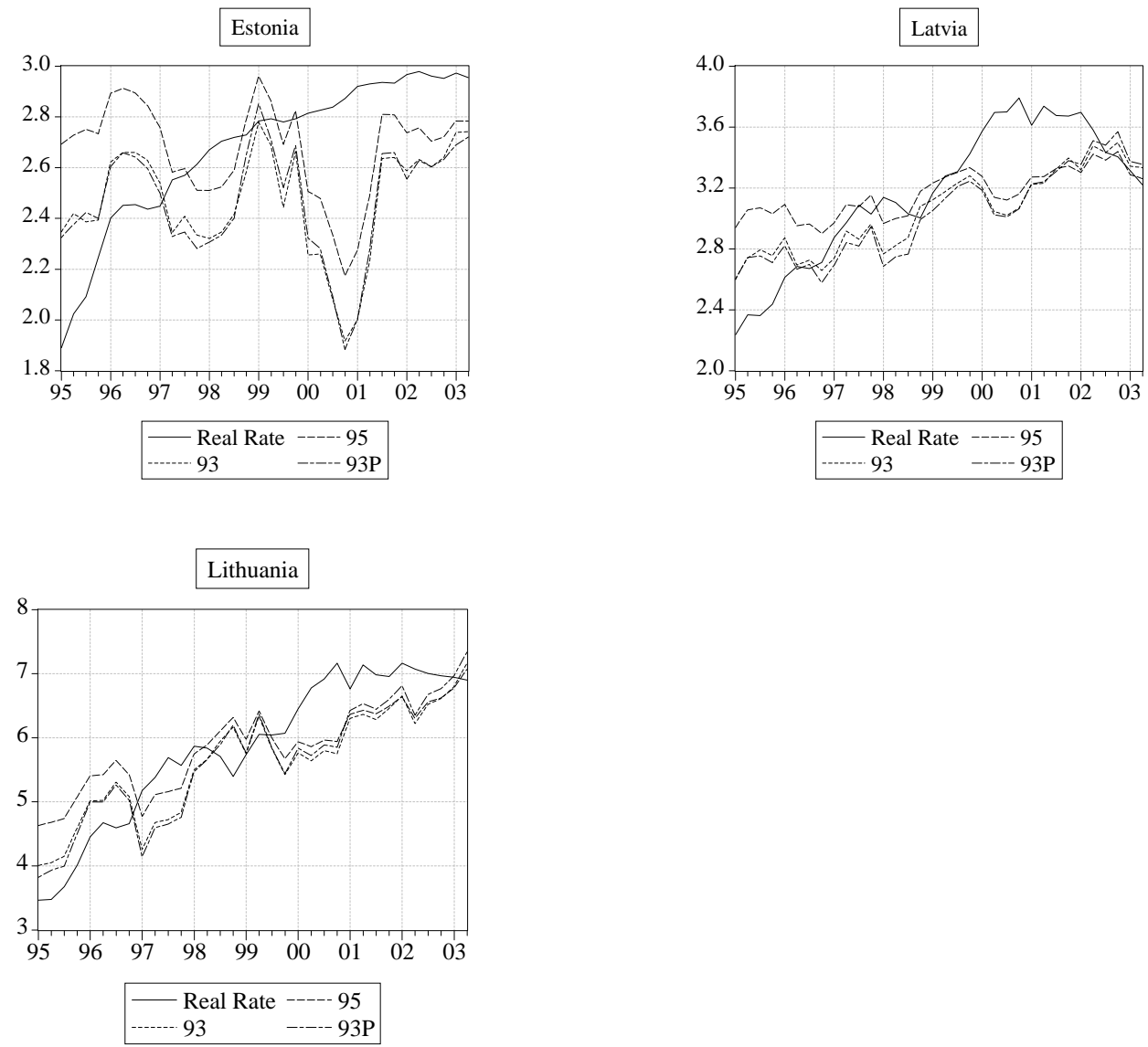
Figure 3 Actual and Estimated Real Exchange Rates (Central Europe)
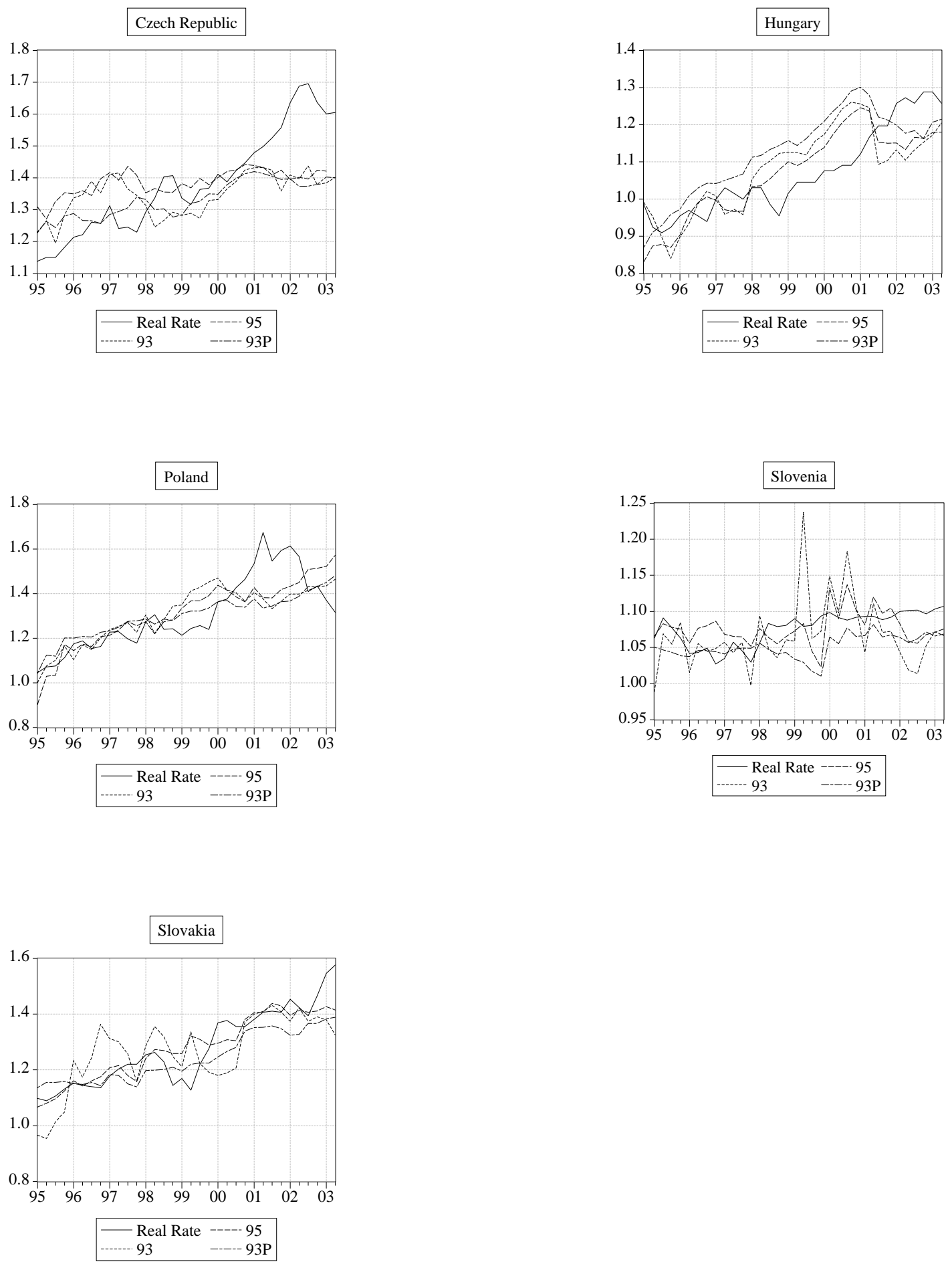